\title{
Quiet Alf
}

\section{Graeme Wells ${ }^{1}$}

Alf Hagger, the economist most singly responsible for the advent of the postwar 'quantitative revolution' in Australian economics, has died in Hobart at the age of 88 .

Alf was born in the Melbourne suburb of Preston in 1922, the only son of his namesake, a proprietor of a cardboard-box factory. While the home of the family of four was in Preston, the Haggers had strong links to the inner-city suburb of Fitzroy and even stronger links to the sporting clubs that bore that name, the Fitzroy Cricket and Football Clubs. Alf worked his way up through church cricket to play for Fitzroy; later, he loyally stuck with the Lions football team when they merged with the Brisbane Bears.

Leaving Melbourne High School at the end of 1938, he went on to the University of Melbourne to study Commerce in the shadows of war between 1939 and 1942. He served in the University Rifles, along with economist Peter Karmel (who was the cook). Later, despite his wish to serve in the Navy, Alf was 'drafted' to work in the Department of Manpower and National Service. He served with distinction and, at the end of the war, the best and brightest of those recruited into the Public Service were given the opportunity to take up permanent careers. Alf was one of those selected. He joined the Commonwealth Bureau of Census and Statistics, then under the direction of Roland Wilson. A year or so later he was seconded, presumably by Wilson, to work with Sir Douglas Copland, the first Vice Chancellor of the Australian National University.

Some years later, when recommending him for promotion at the University of Tasmania, the professors referred to Alf's 'amazing capacity for work requiring sustained concentration'. Most likely, his secondment at the ANU made more use of this capacity than his abilities as an economist. In any event, Copland was influential in securing for Alf a scholarship to the London School of Economics.

His time in London was well spent - while at the LSE he met Rona, with whom he was to have two children, Michael and Stephanie. Under Ralph Turvey's supervision, he completed his doctorate in 1952, writing a thesis entitled An Analysis of Some Recently Developed Methods of Forecasting Aggregate Spending'. Importantly for his later research and teaching, he was at the LSE

1 University of Tasmania; Graeme.Wells@utas.edu.au. I gratefully acknowledge assistance from and discussions with Don Challen, William Coleman, John Grant, Nic Groenewold and Michael Hagger. 
when important advances were being made in mathematical economics and econometrics (later generations of Alf's students recall being directed to R. G. D. Allen's Mathematical Economics when help was required).

On graduating, he was almost immediately recruited by Gerald Firth as part of the post-war re-staffing of the Faculty of Economics at the University of Tasmania.

The University he joined was in a sorry state. After years of dissatisfaction regarding working conditions and academic governance, a Royal Commission had been established in 1955 to make a comprehensive inquiry into the University, with particular emphasis on the relationship between the academics and the Council of the University. ${ }^{2}$ A year later, the Council dismissed the Professor of Philosophy, Sydney Orr, for improper conduct (he was accused of seducing one of his students). The Orr affair was to divide the small university community long after Orr's death in 1966.

Alf did not allow himself to be distracted. He quickly made his mark at the University of Tasmania, and in Australian economics, by his quantitative approach to economic research. Many of his publications in the 1950s use mathematical tools to correct or clarify propositions which, at the time, were being loosely made using verbal arguments. His later colleague Professor John Grant recalls that in his first year at the University Alf established the first course given in Australia in econometrics, based on the then new books by Klein, Tinbergen and Tintner — later, with Don Challen as co-author, Alf was to produce a series of well-received texts and monographs on the use of econometric modelling for policy.

During the 1960s his attention turned from investigations of Keynesian nationalincome analyses towards a study of inflation, and an important theme running through his macroeconomics research was its emphasis on labour markets and the measurement of excess demand. Alf's later move to regional economics coincided with his growing involvement with the Centre for Regional Economic Analysis and continued for the most part his interest in labour markets. One of his early contributions examined the way in which industry contributions to regional employment could be measured, an issue with which CREA had to grapple early in its existence. Subsequent work broadened to an analysis of unemployment, both at the national level and for regions. His most recent research in regional economics involved theoretical and simulation models with maximising regional governments.

2 On one account 'Staff were poorly paid and poorly regarded, with non-academic members of council deriding academic work, contemptuous of research and uninterested in questions of salaries and conditions' (Pybus 1993: 47) 
As the only member of the Department of Economics with a $\mathrm{PhD}$, and one of the few who published regularly, Dr Hagger was held in awe by his students. His patience and skill as a supervisor and mentor resulted in productive collaborations with his former students, most notably Don Challen and Nic Groenewold. He was by no means an entertainer. As Nic remembers:

I remember being a little disappointed - average height, not at all distinguished-looking. When he spoke, it was the same: a normal Australian accent, not an imposing voice, not an authoritative lecture style. His teaching method was quiet and methodical. He told me later that he has always been of the view that it is more important to teach a modest amount thoroughly than to attempt to cover all the fashionable topics superficially. I have often thought of him when I have been critical of the more recent university practice of relying on 'student evaluation of teaching'. He is the prime example of a lecturer who was first-rate but would have fared very badly in today's popularity contests which are 'student evaluations'. There was no flair, no entertainment, no jokes (or none that I understood) but if at the end of the lecture you didn't understand, it was because you hadn't paid attention.

Alf was elected to the Academy of Social Sciences in Australia in 1981, and retired from the then Department in 1982. Few would have anticipated that he was only halfway through his productive career - in the following three decades he produced eight books, more than 20 journal articles, and more than 30 CREA publications.

The Centre for Regional Economics was the first research centre outside the physical sciences within the University of Tasmania. Its funding model relied on grants from the State Government and, for a short time, from the Commonwealth Government, together with income from consultancies and other fee-for-service work. Alf Hagger was a crucial part of the effort involved in the creation of CREA, the establishment of its operating model and winning the grants and work fundamental to its survival and growth. Most importantly, he was one of the mainstays of the intellectual effort over a period of 20 years, on which CREA's reputation rested and without which CREA could not have survived and prospered the way it did. CREA made a major mark in regional economics and, together with John Madden, the credit for that goes to Alf.

Alf, with some co-authors, wrote a number of books on the role of economists in Australia. Exasperating Calculators defends economic analysis and economic advice against ill-informed and misleading criticisms. In Giblin's Platoon and Torliev Hytten he explores the role of a group of influential economists from the 1920s to the 1950s, all with a Tasmanian connection. He was working on the biography of another Tasmanian, Arthur Smithies, when he died. 
Alf believed that the work of economists - rigorous and quantitative analysis - is crucial for policy. This ideal drove his research and teaching. So, while he never became enmeshed in the policy-making process, his heroes were those who were able to make significant contributions both to economic analysis and to the implementation of soundly based policy.

\section{Selected Publications of Alf Hagger}

\section{Books}

The Theory of Inflation: A Review, Melbourne: Melbourne University Press, 1964.

Price Stability, Growth and Balance: Australia's Economic Objectives, Melbourne: Melbourne University Press, 1968.

The Objectives of Macro-Economic Policy (with A. J. Dasgupta), London: Macmillan, 1971.

Inflation: Theory and Policy, London: Macmillan, 1977.

Modelling the Australian Economy (with D. W. Challen), Melbourne: Longman Cheshire, 1979.

Macroeconometric Systems: Construction, Validation and Applications (with D. W. Challen), London: Macmillan, 1983.

Exasperating Calculators: The Rage over Economic Rationalism and the Campaign against Australian Economists (with W. Coleman), Paddington, NSW: MacLeay Press, 2001.

Economics in the University of Tasmania: The First One Hundred Years, Hobart: University of Tasmania, 2004.

Giblin's Platoon: The Trials and Tribulations of the Economist in Australian Public Life (with W. Coleman and S. Cornish), Canberra: ANU E Press, 2006.

Torliev Hytten, Hobart: ACYS Publishing, 2007.

\section{Journal Articles}

'The Analysis of Two Simple Models', Yorkshire Bulletin of Economic and Social Research, July 1954. 
'The Balanced Budget Theorem', Economic Record 31(60), 1955.

'Planned Saving and Investment under Conditions of Steady Growth', Review of Economics and Statistics 38, November 1956.

'Multiplier Theory and Fiscal Policy', Review of Economic Studies 24(3), 1957.

'Three Concepts of the Multiplier', Southern Economic Journal 24(1), 1957.

'Mr Kurihara's "Secular Macro-Economic Theorems"', Indian Journal of Economics, October 1958.

'A Note on the Marginal Efficiency of Capital' (with J. D. Pitchford), Economic Journal 68(271), 1958.

'Bent Hansen's Inflation Theory', Yorkshire Bulletin of Economic and Social Research 13(2), 1961.

'Some Gaps in the Theory of the Inflationary Process' Economic Record, March 1965.

'Price Determination in Models of the inflationary Process', Economic Record 41(43), 1965.

'The Role of Excess Demand in the Australian Price Equation' (with D. W. Challen), Economica 45(178)., 1978.

'Demand for Labour Functions: The Wrong Track?' (with D. W. Challen), Oxford Bulletin of Economics and Statistics 44(1), 1982.

'Another Look at Australia's Inflation-Unemployment Trade-Offs' (with D. W. Challen), Australian Economic Papers 14(25), 1975.

'The Natural Unemployment Rate in Australia since the Seventies' (with N. Groenewold), Economic Record 74(224), 1998.

'Regional Unemployment Dynamics: The Big Neighbour Effect' (with N. Groenewold), Australasian Journal of Regional Studies 1(2) 1995.

'Competitive Federalism: A Political-Economy General Equilibrium Approach' (with N. Groenewold and J. R. Madden), Australasian Journal of Regional Studies 6(3), 2000.

'Time to Ditch the Natural Rate?' (with N. Groenewold), Economic Record $79(246), 2003$.

'Natural Rate Estimates for the Australian States: An SVAR Approach' (with N. Groenewold), Regional Studies 37(3), 2003: 251-63. 
Agenda, Volume 18, Number 1, 2011

'Regional Unemployment Disparities: An Evaluation of Policy Measures' (with N. Groenewold), Australian Economic Papers 47(4), 2008: 355-75.

\section{Reference}

Pybus, C. 1993, Gross moral turpitude: the Orr case reconsidered, Port Melbourne: William Heinemann Australia. 